is growing and it is hoped that the marsh can be used to educate and inform people about the importance of such sites and the need for their conservation.

Further information about the Barvas area and the multispecies inventory can be obtained from DU-Yorkton. All inquiries are welcome.

- Mark Kornder, Ducks Unlimited Canada, 4-17 Fifth Avenue North, Yorkton, SK. S3N OY9 and Ken Belcher, 1121 Seventh Street East, Saskatoon, SK. S7H OY9

\section{A SECOND BREEDING RECORD OF RED CROSSBILL IN REGINA}

On 26 September 1989 at approximately 10:45 a.m. Elmer L. Fox and I watched a pair of Red Crossbills (Loxia curvirostra) feeding a fledgling in a tall spruce west of the Bandshell near the Albert Street Memorial Bridge in Regina. This observation represents a second breeding record for Regina. In Birds of Regina (Rev. 1980-SNHS Special Publication No. 12), M. Belcher reports that Dr. G.F. Ledingham observed a similar incident on 30 May 1976, citing it as a breeding record.

- Frank H. Brazier, 2657 Cameron Street, Regina, SK. S4T 2W5

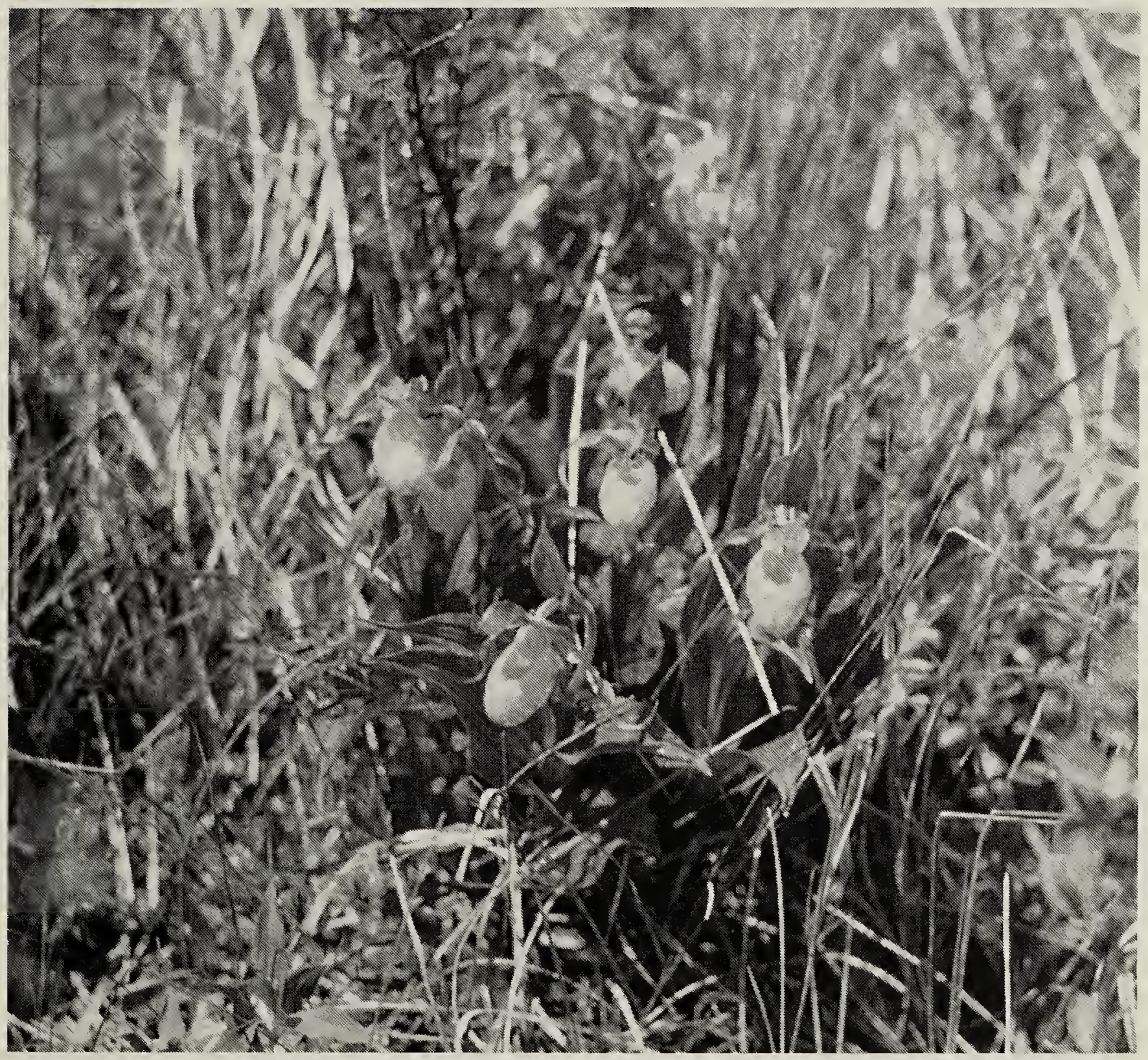

The rare Large Yellow Lady's Slipper

Ken Belcher 